\title{
An Analysis on White Cultural Hegemony in The Bluest Eye
}

\author{
Shaohan Bai \\ School of Foreign Languages, Southwest Petroleum University, Chendu, Sichuan, China
}

\begin{abstract}
The Bluest Eye was the first novel of Tony Morrison, a world-renowned black woman writer in the United States. This novel talked about the tragic experience of a black girl Pecola during the Great Depression, revealing the influence of American white cultural values, especially the popular aesthetic standards of the mainstream society on African-Americans. In a society where white cultural values predominate, the prejudice that black equates ugliness has penetrated into every corner of life, including the cultural education of children. In the novel, the upper class of the United States mainly brainwashed the African-Americans through the mass media, schools and religions, internalized the values of white people into moral standards of African-Americans, and finally let the African-Americans abandon their racial characteristics and totally lose their voice in American society. This is the main problem that the novel reveals. Under this circumstance, Pecola yearned for blue eyes, blonde hair and white skin. If she acquired all these good things, everything would be totally different for her: she would be lovely and charming, her parents would stop fighting and her father would give up drinking, etc. to name just a few. However, when someone really took notice of her, tragedy befell her: her drunken father raped her, and impregnated her, which contributed to her insanity. This thesis mainly studies the phenomenon of cultural colonization and cultural hegemony in The Bluest Eye. It also reveals the influence of cultural hegemony on African-Americans, and explores the self-worth and culture of African-Americans. In today's global trend, mainstream culture poses a threat to many ethnic minorities and deprives social groups in economic, political and cultural terms. It is still an unavoidable theme for them to survive and maintain their own culture and tradition. Therefore, analyzing this novel from the perspective of cultural hegemony has certain practical significance.
\end{abstract}

Keywords: The Bluest Eye, Cultural Hegemony, White culture, African-American culture.

\section{Introduction}

The Bluest Eye tells the hegemonic effect of white culture in the mid-20th century on African-American culture in the United States. Taking the black little girl Pecola as the main character clue, it tells the story of Pecola's loss of self and denial of self under the influence of white cultural hegemony. This work is not only a description of the tragic fate of the little girl, but also shows the hegemonic influence of the white culture on the development of African-Americans through the fate of the characters, and reveals the persecution of the black group caused by racial discrimination, which deserves people to ponder.

\subsection{Tony Morrison and Her Literature Achievements}

Tony Morrison is an African-American female Nobel laureate and one of the most famous black novelists. She is a prolific writer and has published 10 novels, The Bluest Eye (1970), Sula (1973), Song of Solomon (1977), Tar Baby (1981), Beloved (1987), Jazz (1992), Paradise (1999), Love (2003), A Mercy (2008), and Home (2012). Toni Morrison was born in Lorain, Ohio, to Ramah (née Willis) and George Wofford. She is the second of four children in a working-class family. Her mother was a domestic helper and his father was a blue-collar worker. Despite her family's poverty, she lived a happy life under the care of her parents and had a happy childhood. Morrison's love of literature has a lot to do with her family. Her grandfather likes to tell stories. Her mother loves music. She has been influenced by African-American culture since she was a child. Growing up in such a family environment creates an artistic atmosphere for her later literary creation. Her novels are known for their epic themes, vivid dialogue, and richly detailed characters.
Since the 1970s, Morrison has been teaching black literature at many universities in the United States in the hope of giving people a better understanding and accepting of the value of black literature. Morrison's literary creation had an important influence on the development of literature, and she won the Nobel Prize for literature in 1993. She uses her imagination to make a detailed portrayal of the real society, so that readers can understand the content of the work and think about the real society.

\subsection{Literature Review}

In the 1960s and 1970s, African-Americans are politically oppressed, economically exploited, and discriminated against in their lives. Historically, they have done a lot of resistance and struggles to dispel slavery and strive for ethnic peace. American black literature began in the 18th century. Under the unremitting efforts and inheritance of black writers, its development experienced three climaxes. First, the Harlem Renaissance led by Langston Hughes in the late 1920s and 1930s. Then came the second climax of Richard Wright in the 1940s and the third climax of Tony Morrison as the leader after the 1970s.

In the two climaxes of the 20th century represented by black male writers in the United States, a large number of writers' works have focused on ethnic issues. Most of them describe the persecution and discrimination of African-Americans in politics, economy and society. With the representative of Jean Toomer, Richard Wright, Ralph Ellison and James Baldwin, etc., the protagonist in the work shows a kind of incompatibility with the white society, and the scene of confrontation, black and white, black society and white society are completely two kinds of counter-states. For white culture, African-Americans seem to have natural resistance. Morrison is the main representative of the third wave of black 
American literature. At the beginning of her literary career, she set her sight on black women which were ignored by other writers.

Foreign research on Toni Morrison begins with Joan Bischoff's Morrison's Novel: Exploring Frustration, published in 1975. This article compares the themes of Morrison's first two works, focusing on the analysis of the moral tensions in Morrison's work and the universality of her work. Since then, the United States has published the first monograph on Toni Morrison, The World of Toni Morrison: The Adventures of Literary Criticism co-authored by Bessie Jones and Order Vincent, which contains several stories about Morrison's novels and Morrison's interview record, which marks a new height in the study of Morrison's novels by American literary criticism.

The study of "The Bluest Eyes" in China is basically based on Sex, Race, Culture: Morrison's Novel Creation by Wang Shouren and $\mathrm{Wu}$ Xinyun in 1999. After entering the 21st century, the research articles of The Bluest Eye had made great breakthroughs, and had achieved certain research results. Therefore, more and more scholars have begun to join the study of African-American writers and their works. Among them, Morrison began to be the focus and research of more scholars as a black female writer.

This paper not only exposes the hegemony of white mainstream culture to African-Americans, but also explores African-American culture and its values, suggesting the potential resistance of African-American culture reservation to white cultural hegemony. Petra's tragedy undoubtedly proves to the world that African-American blacks cannot afford to lose their traditional culture when they accept the value system of white culture. Only rooted in the culture of their own nation can the black individual finds their value and identity.

\section{White Cultural Hegemony in This Novel}

The mainstream culture of American society was influenced by Europe and began to colonize other cultures in the country. African-Americans and other minorities in the United States have been trying to integrate into the mainstream society in the United States, eager to gain identity from mainstream culture. As early as the beginning of the establishment of slavery, white Americans have enacted a series of laws to legalize slavery and deprive African-Americans' human rights. The economic and educational disadvantages of African-Americans after the Civil War made them struggle on the road to freedom and equal rights. The southern white regime did not dare to publicly deprive African-Americans' rights to vote, but they used head tax, cultural tests and grandfather clauses, to limit the African-Americans' rights, and finally deprived the African-Americans' rights. Apparently, the history of the United States is the history of the abuse of the human rights of African-Americans in the mainstream of the European society. It is the colonial history of European whites against black politic, economy, culture, and education. In this society with internal colonization, African-Americans eventually became victims of the white culture hegemony.

\subsection{The Erosion of the White Culture}

The core part of The Bluest Eye is the aesthetics under the mainstream culture of the United States which promotes the aesthetic values based on the physiological characteristics of white people, while the blackness has been discriminated against as the opposite. This concept has long brought African-Americans a self-defeating mental pain. As a society controlled by European-American whites, its aesthetic standard is based on the physical characteristics of European whites. The white-skinned, blond-haired, and blue-eyed female images are set as aesthetic standards which will inevitably lead to the negation of African-Americans. In the novel, all women judge themselves and everything around them according to the white aesthetics. Every black woman is eager to get rid of the blackness and get closer to the white aesthetic standards.

The aesthetic tendency of mainstream society has spread to the sub-cultural groups through the mass media, such as movies, newspapers, posters, advertisements, etc., and this has formed a unified ideological model. The influence is subtle. The African-Americans unwittingly internalize the white aesthetic standards as their own ruler, so that "all adults, older girls, shops, magazines, newspapers, shop posters and even the whole world agree that blue-eyes, golden-hair, pink-skinned dolls are something that every girl should cherish". Under the conflict between white aesthetics and the physical characteristics of African-Americans, the aesthetics of African-Americans have become alienated, and finally formed a kind of "hybrid culture".

\subsection{The Internalization of Racism}

Racism internalization refers to the fact that African-Americans have been enslaved in the long-term enslavement, and under the subtle influence of dominating culture, they have recognized the worst part of white culture - racial discrimination. It makes the wife despises her husband, the mother dislikes her children, the African-Americans laugh at the blackness of other African-Americans, and create a self-defeating black male like Cholly, which aggravates the suffering of black women. What's more, some African-Americans treated their compatriots viciously with "second-hand racial discrimination." Unlike Pecola's parents, some of the light-skinned African-Americans in the black community of Laurie have taken the initiative to recognize the superiority of the white ruling class and pander to the ruling foundations of American domestic imperialism such as lifestyle, way of thinking, and value standards.

In this novel, Geraldine's personality is the product of accepting and pandering to the leadership of domestic imperialism in the United States. She went to normal school to learn how to serve white men, how to teach black children to obey those in power, how to develop a lifestyle consistent with the moral norms of the ruling class. But her character was distorted by it. Her education made her quiet, elegant, frugal and hygienic, which were good traits. But she deliberately pursued the perfect demeanor, deliberately removed her passion, nature. At last, she lost her human nature and feelings. 
She believes that exaggerated movement, loud laughter, curly hairs or thick lips are indecent black features. She gave her son everything but did not give him love. She maliciously cursed the black girl Pecola. Like the white shopkeeper who looked down on Pecola. Unfortunately, her pursuit, her understanding of life, her efforts to make herself closer to the standard of white males' appreciation of women, do not allow her to avoid racism. She separates herself from the African-Americans, and the whites separate her from them.

To say the least, most African-Americans at that time did not emerge from the shadow of psychological slavery. They were controlled by the cultural consciousness of imperialism and could not form a heathy personality. Just as the narrator, Pecola's playmate, Claudia's reflection, Pecola's tragedy is the fault of the land.

I even think now that the land of the entire country was hostile to marigolds that year. This soil is bad for certain kinds of flowers. Certain seeds it will not nurture, certain fruit it will not bear, and when the land kills of its own volition, we acquiesce and say the victim had no right to live. We are wrong, of course, but it doesn't matter. It's too late. (Morrison, 1970: 168)

Marigolds represented the African-Americans who were marginalized by the colonization. The land represents the political system of the United States, and its "kills of its own volition" reflects the will of the imperialist superstructure. The author borrowed the speech of Claudia to torture the souls of everyone's and questioned their role in the Pecola's tragedy. Although this hindsight is too late, efforts to consciously resist white cultural dross will never be late.

\section{The Effect of White Cultural Hegemony}

In The Bluest Eye, the white class mainly influences the ideology of African-Americans through institutions such as mass media, school education, and churches. In the end, the white values were infiltrated into the black mind, which lead the African-Americans to agree with the white aesthetics that white skin is beautiful and black skin is ugly, gradually abandoning the blackness. Pauline and Pecola internalized white values and sacrificed their lives for the white aesthetic standards. Cholly was subjected to double oppression by whites and white cultural hegemony, which eventually led to personality splitting.

\subsection{Tragedy of Pecola}

Pecola is the main character of this novel, born in a poor black family, without care of her parents. Her mother Pauline pursues the white lifestyle and is influenced by the white culture. Therefore, Pecola wants to get the care of her parents and get a happy life, but her actual life is unfortunate. Her mother would rather work for a white family than to admit that Pecola is her daughter. Her father finally raped her and made her pregnant, which made her ridiculed at last. Influenced by white culture, the black group also like to use white eyes to observe the people around them. For this reason, they think that Pecola is ugly, and also think that blue eyes are beautiful.
When Pecola accidentally knocked over the white protagonist's strawberry pie, her mother, Pauline, did not care for her daughter, nor did she feel that whether Pecola was burnt by the strawberry pie or not, but instead gave Pecola a slap in the face. This behavior was mainly because Pauline thought that Pecola had soiled the floor of the white host and scared the little white girl. But Pauline completely forgot that she was Pecola's mother. She also forgot her family responsibilities. She didn't want to admit that Pecola was her own daughter. In such a living environment, Pecola hopes that she can have a pair of blue eyes, live happily like the little white girl. By reading this novel, it can be found that Pecola, like her mother, is influenced by the white culture and hopes that she can get the life of the little white girl, so she is obsessed with blue eyes. Pecola is eager to be treated fairly, hoping to see a purer and a better world through the blue eyes. It can be said that Pecola is a typical victim of white cultural hegemony. Under the influence of the mainstream culture created by white people, the black groups represented by Pecola gradually lose their self-recognition, have distorted value cognition, accept the criterion of white people's judgment on them, and the original national power is gradually decomposed. African-Americans have gradually become a marginal group in American society.

\subsection{Tragedy of Pauline}

Pauline is Pecola's mother and also a major figure which was controlled by the white culture in this novel. By analyzing her, we can grasp the specific ways in which white culture control the African-Americans and the influence on the development of African-Americans.

By reading this novel, we can find that the way whites conduct cultural hegemony against African-Americans is the medium. Through the media, the white people's thoughts and influences caused great persecution to African Americans at the time. In this novel, Pauline's fate is also tragic. Through the film and television media, white people show their cultural ideas to the black groups, and they control the culture through the cultural media, let the African-Americans accept the values that the whites agree with, which makes the African-Americans' life more embarrassing. In order to get a higher level of material life and change the reality of the previous embarrassment, Pecola's parents came to the north, but when they came to the north they did not get the desired life, but were poisoned by white culture and lost faith in future life. Pauline was ridiculed and satirized by local women because of her southern pronunciation accent and rustic dress. At the same time, their reality of survival is also very embarrassed, so the original harmonious relationship between husband and wife gradually broken, the family atmosphere is even worse. Influenced by white films, Pauline hopes to get more satisfaction psychologically so that she can enjoy a better life. Because in white movies the heroine is very beautiful, dressed in fashionable, the way of life is very comfortable, and there is a handsome man who has been deeply in love with her. Pauline has a yearning for such a life; she also has serious dissatisfaction with her current status, and thus pursues the lifestyle and concept presented by white people. However, due to the nature of her group and the restrictions on the living environment of black women, Pauline is far from being able to achieve the same state as the 
protagonist of the film. Therefore, Pauline can't manage her home as neat and beautiful as a white home.

I fixed my hair up like I'd seen hers on a magazine. A part on the side, with one little curl on my forehead. It looked just like her. Well, almost just like. Anyway, I sat in that show with my hair done up that way and had a good time. I thought I'd see it through to the end again, and I got up to get me some candy. I was sitting back in my seat, and I taken a big bite of that candy, and it pulled a tooth right out of my mouth. I could of cried. I had good teeth, not a rotten one in my head. I don't believe I ever did get over that. There I was, five months pregnant, trying to look like Jean Harlow, and a front tooth gone. Everything went then. Look like I just didn't care no more after that. I let my hair go back, plaited it up, and settled down to just being ugly. (Morrison, 1970: 97-98)

Based on such a realistic environment and her own dream of living for the white protagonist, Pauline worked as a servant in a white family, and she was very serious about her work, hoping to gain the recognition of a white family by carrying out domestic work. It can be said that the more the Pauline was impacted by the white culture, the more she wanted to integrate herself into the life of the white group, and the more she ignored her original black family. It can be seen that Pauline is fully acknowledging her current role as a servant, hoping that she can get a better life like a white family and pursue the concept of comfortable life presented in white movies. However, no matter how Pauline works as a servant or how much the white people give her the right to live, she is a servant in the industry, and her life is still low-lying. In order to be accepted by the white people, Pauline threw her family behind her back and lost her original self under the influence of this culture, becoming a tributary of white development. Under the influence of the white cultural thoughts, Pauline gave up his black cultural attributes, judged her own culture with the white mainstream culture, and gradually lost her own culture.

\subsection{Tragedy of Cholly}

The impact of white cultural hegemony on African-Americans is reflected not only in white discrimination against the black community, but also in the use of white value perceptions by many African-Americans to evaluate their compatriot around them. The most obvious oppression is the oppression of the gender dimension-black men often release their anger from white oppression on black women, using oppression of women in exchange for their self-esteem. In this novel, Pecola's father, Cholly, is a representative of the oppression of other black women under the white culture hegemony.

Cholly was free. Dangerously free. Free to feel whatever he felt--fear, guilt, shame, love, grief, pity. Free to be tender or violent, to whistle or weep. Free to sleep in doorways or between the white sheets of a singing woman. Free to take a job, free to leave it. He could go to jail and not feel imprisoned, for he had already seen the furtiveness in the eyes of his jailer, free to say, "No, suh," and smile, for he had already killed three white men. Free to take a woman's insults, for his body had already conquered hers. Free even to knock her in the head, for he had already cradled that head in his arms. Free to be gentle when she was sick, or mop her floor, for she knew what and where his maleness was. He was free to drink himself into a silly helplessness, for he had already been a gandy dancer, done thirty days on a chain gang, and picked a woman's bullet out of the calf of his leg. He was free to live his fantasies, and free even to die, the how and the when of which held no interest for him. (Morrison, 1970: 132)

Cholly, who passed on his own oppression and disgruntled inner emotions to black women who were weaker than him, was a deformed figure. His wife, Pauline, was influenced by white film and television works, so she pursued a higher level of material enjoyment, but Cholly did not have enough money to satisfy Pauline's pursuit of life. His self-esteem and male dignity were trampled upon, hey felt a deep sense of anger, which he turned into beating his wife. By physically assaulting his wife, Cholly could see his strength as a man and feel his dignity. Under all the oppression of his life, Cholly raped his own daughter, Pecola, to express his feeble resistance to his existing life and his deformed vengeance. It can be said that Cholly is the representative of the black group that was maimed in the process of white cultural hegemony. He could only engage in a cultural revolt in a distorted way, and in the end, it was still tragic. Under the influence of white cultural hegemony, Cholly gradually lost himself, could not face himself, could not take responsibility for his own family, and everything he did was a powerless confrontation.

\section{Approaches to the Rebuilding African-Americans' Identity}

In this novel, what Morrison wants to appeal and express is not to let African-Americans realize the strength of white culture, but to preserve the culture of their own race. Only when their culture is strong enough, can they discard the dross and select the essence in the face of the invasion of a dominating culture. Morrison reveals the essence of white cultural hegemony through her own works, to arouse the awakening of African-Americans, and let African-Americans realize the truth of white cultural hegemony, which is an impact on the mainstream culture of white people.

\subsection{Appreciation of the Black Self}

Most of the novels are narrated by Claudia as the first person. She is a nine-year-old black girl with a stable family. Although she was also oppressed by whites, she still insisted on her black identity and loved the African-American culture. Claudia is one of the few characters in the novel who dares to resist white aesthetics. When she received a blue-eyed, yellow-haired, pink-skinned rag doll at Christmas, Claudia felt that the gift did not bring her happiness. Instead, she had disgusted and feared the doll. Claudia didn't know if the rag doll was beautiful, but the black women around her thought it was the most beautiful ragdoll in the world. As Morrison said:

But I could examine it to see what it was that all the world said was lovable. Break off the tiny fingers, bend the flat feet, loosen the hair, twist the head around, and the thing made one sound--a sound they said was the 
sweet and plaintive cry "Mama," but which sounded to me like the bleat of a dying lamb, or, more precisely, our icebox door opening on rusty hinges in July. Remove the cold and stupid eyeball, it would bleat still, "Ahhhhhh," take off the head, shake out the sawdust, crack the back against the brass bed rail, it would bleat still. The gauze back would split, and I could see the disk with six holes, the secret of the sound. A mere metal roundness. Grown people frowned and fussed: "You-don't know how to-take care of-nothing.

I-never had a baby doll in my whole life and used-to cry my eye sout for-them.

Now-yougotoneabeautifuloneand-youtearitupwhat'sthe matterwith-you?" (Morrison, 1970: 15)

Claudia ruined the dolls, but she was reprimanded by the adults. They were so eager to have a doll when they were young, but they couldn't get it. Claudia dismantled it after she got the doll. The essence of dismantling the doll is a rebellion against the white. What had Claudia ruined was not a simple doll, but a beautiful doll that represented the white aesthetic standards. It was a perfect white figure doll with white skin, blue eyes and yellow hair. Claudia's dismantling of the doll was an awakening of African-Americans under white ideology, an act of preserving the confidence and self-esteem of the black race.

Claudia's Christmas wish was never a doll, it was the adults who took it for granted that Claudia liked white-skinned, blue-eyed dolls.

"Dear Claudia, what experience would you like on Christmas?" I could have spoken up, "I want to sit on the low stool in Big Mama's kitchen with my lap full of lilacs and listen to Big Papa play his violin for me alone." The lowness of the stool made for my body, the security and warmth of Big Mama's kitchen, the smell of the lilacs, the sound of the music, and, since it would be good to have all of my senses engaged, the taste of a peach, perhaps, afterward. (Morrison, 1970: 16)

Claudia bravely expressed her desire here, eager to get what she wanted rather than what others thought she wanted. Claudia can destroy the doll's body, but will not destroy the majority of African-Americans' ingrained white skin, blue eyes, and yellow hair aesthetic standards. But as long as the African-Americans are level-headed, it can still retain the aesthetic of African-Americans, the culture of African-Americans, and the race of African-Americans.

\subsection{Maintaining Their Own Culture and Tradition}

In The Bluest Eye, there are black women like Paulina, Pecola, and Geraldine who accepted and internalized white values, but there are also black women like Poland, China and Miss Mari who rejected white culture and praised traditional African-American culture. In the dreary atmosphere of the novel, they are a tiny number of characters who have an optimistic state of mind. They live in the apartment above the Breedloves' storefront. "Pecola loved them, visited them, and ran their errands. They, in turn, did not despise her." (Morrison, 1970: 42)

In Pecola's eyes, their house is like heaven, because she was recognized there, and she could be aware of her beauty and loveliness. The friendliness and love of the three prostitutes to Pecola are invaluable in a community where African-Americans do not lend a helping hand and do not show a tolerant smile. They never despise Pecola. Poland likes singing, and Mary likes to give Pecola a variety of lovely nicknames. Their homes are often filled with laughter.

All three of the women laughed. Marie threw back her head. From deep inside, her laughter came like the sound of many rivers, freely, deeply, muddily, heading for the room of an open sea. China giggled spastically. Each gasp seemed to be yanked out of her by an unseen hand jerking an unseen string. (Morrison, 1970: 43)

They have fewer chapters in the book, and their careers determined that they are bound to be classified as the lowest figures in society. In the novel, they are looked down upon by African-Americans. Mrs. McDill let the Claudia sisters stay away from the three prostitutes because they were destroyed. Ironically, such three marginalized women, under the impact of a dominating white culture, still maintain their own independence and their own culture. The three prostitutes who were destroyed were physically destroyed and no longer innocent, but their minds were independent, and they were the most innocent in spirit compared to other African-Americans who had been destroyed in their minds by white cultural hegemony. They still retain their black self-awareness in dominating white culture hegemony, and are invaluable in preserving the racial identity of African-Americans.

This shows that African-Americans cannot accept a value system dominated by white culture at the expense of breaking away from the traditional culture of their own. African-Americans can only maintain their identity through the appreciation and protection of African-American culture.

\section{Conclusion}

In The Bluest Eye, Morrison shows the spiritual distortion and self-lost by depicting African-Americans under the influence of white culture hegemony, telling readers that using white culture and lifestyle as a value orientation will make African-Americans full of inferiority and confusion. If African-Americans give up their own national culture, they can only get lost in the cultural shock of white people, causing a tragedy like the Pecola's family. Morrison believes that in order to survive, the African-Americans must retain their own culture in addition to their political rights and economic independence. This is also the advanced point of this novel, and it is also an important reason that is still popular.

Only by establishing their own complete value system can African-Americans are able to maintain self-esteem and self-confidence in the face of a dominating culture and maintain their self-confidence in ethnic culture. In order to be recognized by white people and truly integrated into American society, African-Americans must first affirm their own culture and then absorb the excellent parts of white culture. Only then can American society accommodate the 
existence of African-American culture and truly recognize that African-Americans are Americans who are no different from the whites; can African-Americans win the political and economic power they should have; can African-Americans win their dual independence of body and spirit; can African-Americans not adhere to white culture and maintain an independent African-American culture. Meanwhile we have to recognize that this process is long-lasting and difficult. Even today, racial discrimination is still not completely eliminated, and the American white class must be more tolerant, to accommodate the racial identity of African-Americans and to respect the culture of African-Americans.

\section{References}

[1] Alexander Allen. The Fourth Face: The image of God in Toni Morrison's The Bluest Eye [J]. New York: African-Americans Review, 1998 (01): 293.

[2] Duvall N. John. The identifying fictions of Tony Morrison: Modernist Authenticity and Postmodern Blackness [M]. New York: Palgrave TM, 2000.

[3] Kathryn, A. Woolard. Language variation and cultural hegemony: toward an integration of sociolinguistic and social theory $[\mathrm{J}]$. American Ethnologist, 1985, 12(4): 738-748.

[4] Lears T. J. Jackson. The concept of cultural hegemony: Problems and possibilities [J]. The American Historical Review, 1985, 90(3): 567.

[5] Morrison Toni. The Bluest Eye [M]. New York: Holt, Rinehart and Winston, Inc., 1970.

[6] Ogunyeni C. O. Order and disorder in Tony Morrison's The Bluest Eye [J]. Critique, 1977, 19(1): 112-120.

[7] Paramita Dana. Book review of the Bluest Eye written by Tony Morrison [J]. Journal on English Language, Culture and Literature, 2015, 4(4): 14-17.

[8] Rigney B. H. The voices of Toni Morrison [J]. Annals of the New York Academy of Sciences, 1991, 20(1): 295-354.

[9] Ron David. Toni Morrison explained: A reader's road map to the noble [M]. New York: Random House, 2000. 